\title{
Influence of Fieldwork on the Preparedness of Food Technology and Bioengineering students for the Job Market: A Case study of EAPI Student Skills Enhancement Program
}

\author{
Julia Kigozi ${ }^{1}$, Emmanuel Baidhe ${ }^{1}$, Ivan Muzira Mukisa ${ }^{2}$, Charles Muyanja ${ }^{2}$, \\ Leatitiah Namubiru ${ }^{3}$ \& Brenda Katarikawe ${ }^{3}$ \\ ${ }^{1}$ Department of Agricultural and Bio-systems Engineering, Makerere University, Kampala, Uganda \\ ${ }^{2}$ Department of Food Technology and Nutrition, Makerere University, Kampala, Uganda \\ ${ }^{3}$ Uganda Export Promotion Board (UEPB), Kampala, Uganda \\ Correspondence: Julia Kigozi, Department of Agricultural and Bio-systems Engineering, Makerere University, P. O. \\ Box 7062, Kampala, Uganda. Tel: 256-772-609-649. E-mail: jbulyakigozi@yahoo.com
}

Received: January 27, 2021

doi:10.5430/bmr.v10n3p22
Accepted: June 21, 2021

Online Published: November 1, 2021

URL: https://doi.org/10.5430/bmr.v10n3p22

\begin{abstract}
This study aimed at evaluating the influence of fieldwork on the professional and personal skills among Food Technology and Bioengineering (FTB) students of Makerere University. The data was obtained from 40 respondents from three FTB programs (Food Science and Technology, Human Nutrition, and Agricultural Engineering). A semi-structured electronic questionnaire was used to collect the data. The questionnaire comprised of Part 1: Student biography, Part II: Participation in the EAPI student skills enhancement program, Part III: Professional skills, and Part IV: Personal growth. Part I and II consisted of closed-ended questions while Part III and Part IV were evaluated on a 5-point Likert scale (1- Strongly disagree and 5 - Strongly Agree). Descriptive analysis was used to evaluate the student demographic information and participation in the student enhancement program. The reliability of the Likert scale for professional development and personal growth was determined using the Cronbach's alpha index. The study results indicated that $60 \%(\mathrm{n}=40)$ of the respondents better understood their career goals through fieldwork, $83 \%(\mathrm{n}=40)$ increased their skills and knowledge in performing particular tasks, $55 \%(\mathrm{n}=40)$ changed their attitude and feelings about self and others, while $75 \%(\mathrm{n}=40)$ had the opportunity to apply theoretical concepts to the actual work environment. Fieldwork stimulated the FTB students' interest in the field of food processing, mindset change especially concerning job creation, conduct, and prospects. The study findings explain the need to adjust the mode of knowledge delivery and dispensation at the Higher Education Institutions to reduce the rate of unemployment and improve the employability of students.
\end{abstract}

Keywords: food technology and bioengineering students, fieldwork, skills enhancement, employability

\section{Introduction}

No country has achieved substantial economic development without considerable human capital investment (Kefela \& Rena, 2007). Also, notwithstanding the contribution of other factors to the success of an organization, its human resource is most likely to provides a competitive advantage (Wright, McMahan, \& McWilliams, 1994). Higher Education Institutions (HEI) such as universities play a critical role in the development of human capital. HEIs are recognized internationally for feeding important sectors such as health, agriculture, tourism, and civil works with appropriate human capital (HC). $\mathrm{HC}$ is described as the skills, abilities, and knowledge possessed by individuals and acquired through experience, education, and training. These attributes directly relate to the concept of $\mathrm{HC}$ to employability (Aliu \& Aigbavboa, 2019). The International Labour Organization (ILO) describes employability as involving self-belief and the ability to secure and retain employment (Sarkar, Overton, Thompson, \& Rayner, 2016).

The government's deliberate effort to liberalize the economy in Uganda has created a favorable environment for private sector investment in the education sector. With this policy, the government retains the regulatory and supervisory function as well as curriculum development. As a result, many private universities have come up to contribute to human capital development. However, lately, there has been a negative public opinion on the suitability of university graduates for the current Ugandan job market. Similar observations have been made in other countries 
such as Nigeria (Olabanji \& Abayomi, 2019) and Ghana (Biney, 2015). It is worth noting that many graduates in Uganda leave university with no idea how they can start over in case they fail to get employed. It has been observed that the current degree programs offered in Uganda do not enable graduates' abilities in critical thinking, problem-solving, leadership, business mindset, teamwork, creativity and communication, skills that are relevant for the job market. Part of this problem stems from an imbalance between the country's education system and labor markets; the skills that youth need to secure employment are not the skills that they have developed through traditional education (Results for Development Institute, 2013). These disparities between education and professional practice complicate the transition from studenthood to professionalism. According to Muhamad (2012), employers want a little more employability skills rather than just the specialist knowledge gathered during studies. The labor market is rapidly becoming skill-intensive, therefore requiring faster solutions to the employment challenge (Pheko \& Molefhe, 2017).

Strengthening graduate skills and experiences necessary to build successful careers is increasingly becoming important among HEIs as the number of university graduates outweighs the available graduate jobs globally (Peacock \& Bacon, 2018). The Empowerment of the Agro-Processing Industry (EAPI) to meet the Quantity and Quality Standards for the Local and Export Market; a Programme Enhancing the Practical Skills of Students in Makerere University dubbed EAPI Project utilizes the triple helix model (Academia-Industry-Government) to improve the status of Agro-based Micro, Small, and Medium Scale Enterprises (MSMEs) in Uganda. MSMEs and university students (FTB students) constitute a great part of the direct beneficiaries for this project. Under this program, university students are attached to different MSMEs where they support the implementation of project activities while developing hands-on training and experience. Therefore, the students are equipped with skills relevant to the workplace and future entrepreneur development through fieldwork.

Fieldwork was adopted for the FTB programs. However, its effectiveness or potential influence on student employability has not been evaluated in Uganda. The purpose of this study was to evaluate the influence of fieldwork on the professional and personal skills of FTB students of Makerere University upon completion of the EAPI student skills enhancement program. The study also identified the strength and weaknesses of the EAPI student skills enhancement program at Makerere University. This study was particularly important as it avails valuable recommendations to the educational institutions and students concerning the use of fieldwork as a tool for improving personal skills, professional growth, leadership skills, and other work-related experiences of students in Uganda.

\section{Literature Review}

Fieldwork is defined as work done by students to acquire practice experience and knowledge using firsthand real environment observations (Morrissey, Clavin, \& Reilly, 2013). Fieldwork encompasses field teaching, field trips, field research, or field camps, outside the confines of the classroom walls (Baidoo-Anu, Owusu Ansah, Acquah, \& Bentil, 2019). Fieldwork just like internships is a bridge that links the theory studied in class to industrial practice (Anjum, 2020). The concept of fieldwork learning has widely been utilized in geography-related education and the results are impressive (Henry \& Murray, 2018). However, limiting fieldwork learning to courses that are traditionally known to have field-based learning such as geography could be misleading. Instructors in other fields might think that fieldwork learning is only customized for those particular courses (Fedesco, Cavin, \& Henares, 2020). According to Fedesco et al. (2020), it may be harder for educators in other disciplines to predict and appreciate the benefits of fieldwork to students.

Fieldwork provides work-related experience to the students by engaging with members of the communities through service delivery (Naidoo \& van Wyk, 2016). Fieldwork provides the opportunity to reinforce classroom-based learning (Dill, 2017); and it increases students' knowledge, skills, and subject understanding. Fieldwork also provides an 'unparalleled opportunity' to study the real world (Henry \& Murray, 2018; Stokes, Magnier, \& Weaver, 2011). Fieldwork contributes to social interaction and development amongst students and their instructors. A study by Fedesco et al. (2020) reveals that students attributed their sense of closeness with peers and instructors to fieldwork. Despite the registered successes with the use of fieldwork, its adoption into student learning is still low. This could be due to the costs associated with fieldwork, and scheduling difficulties to jargon between classroom time and fieldwork (Baidoo-Anu et al., 2019).

\section{Methodology}

\subsection{Study Population and Sampling Criteria}

Only students that were pursuing FTB (Food Science, Nutrition, Agricultural Engineering, Food safety) at Makerere

University were considered as the population of the study. A total of 41 students participating in the EAPI field 
activities were purposively sampled in this study. The selected students are those that were participating in the EAPI field activities.

\subsection{Description of the EAPI Fieldwork}

Fieldwork was done intensively between January and March 2020. During fieldwork, students were assigned to particular agro-processing facilities. The students worked in teams of 3 to 4 members each. The student groups worked with $3-4$ different agro-processing facilities to increase and widen their exposure. The agro-processing facilities were mainly Micro-, Small-, and Medium-scale Enterprises (MSMEs) that use simples and manual methods for the production of food products. Students worked with agro-processors to develop interventions necessary to improve operations at the facilities. Students supported processors in developing proper record sheets and streamlining documentation; analyzed the process flow and optimized the workspace; troubleshooting the issues associated with spoilage of the processed products; developed and improved Good Management Practices (GMPs); analyzed the possible waste handling strategies at the facilities; assisted processors to understand the basic personal hygiene principles relevant for their facilities; supported agro-processors in the application process for UNBS product standards as well as certification. All efforts were aimed at supporting the agro-processors to obtain certification for their products. The students continuously carried out pre-audits at the different agro-processing facilities to assess their preparedness for the official Uganda National Bureau of Standards (UNBS) certification audit. The fieldwork was closely guided by a team of experts in the areas of food product development, quality assurance and quality control, process flow and design, standards and certification, marketing, product optimization, and GMPs. The fieldwork was limited to enabling students to practice the basic food processing skills that contribute to product certification rather than accumulating marks as it was not graded.

\subsection{Data Collection and Analysis}

The data was collected from students of BSc. Food Science and Technology (BFST), BSc. Human Nutrition (BHN), BSc. Agricultural Engineering (BAGE), MSc. Food Safety and Quality Management (MFSQM), and other freshly graduated students of Makerere University that participated in the EAPI field activities. This is because the program primarily targeted enhancing the practical skills of students at Makerere University.

The data was collected in July $2020\left(1^{\text {st }}-17^{\text {th }}\right.$ July 2020). An e-questionnaire was rolled out via email and WhatsApp to the eligible respondents. The questionnaire comprised of four parts i.e., Part 1: Student biography, Part II: Participation in the EAPI student skills enhancement program, Part III: Professional skills, and Part IV: Personal growth. Professional skills emphasized in the study include teamwork, problem-solving skills, time management, organizational skills, leadership skills, effective communication (written and oral), strong work ethics, enterprise and entrepreneurial skills as outlined by Muhamad (2012), Pheko and Molefhe (2017) and Sarkar et al. (2016). The questionnaires were collected electronically via the KoBoToolbox server. The students were asked to rate the professional and personal skills on a scale of 1 to 5 (1- strongly disagree and 5 -strongly agree).

The study was majorly quantitative, but with some qualitative elements to explain certain elements especially personal growth and impact of the program. The study mainly employed descriptive analysis focused on the measure of central tendencies and dispersion (frequencies, percentages, means, and standard deviations). The reliability of the Likert scale for professional development and personal growth was determined using the Cronbach's alpha index. A reliability coefficient of above $70 \%$ is considered acceptable (Riley et al., 2003). All data analysis was done using Microsoft Excel 2019.

\section{Results and Discussion}

\subsection{Response Rate}

Of the 41 students considered to participate in the study, 40 returned the survey putting the response rate at $97 \%$. This response rate was therefore excellent for analysis and reporting as it is way above the $70 \%$ mark (Tiberious, Mwania, \& Mwinzi, 2016). This could be a result of the numerous reminders sent out to the respondents using WhatsApp.

\subsection{Demographics}

The demographics in Table 1 show that more male students (62.5\%) participated in the study compared to females (37.5\%). By level of education, the majority of the participants were from an undergraduate program (82.5\%). This could have been spurred by the urge among undergraduate students compared to their counterparts at graduate school. The graduate students consider themselves already experienced enough and rarely engage in fieldwork during their training. Their confidence could stem from the internships, and fieldwork conducted at their respective undergraduate schools as well as places of work. Third-year undergraduate students took the greatest share of the participants (57.5\%) 
followed by Fourth years undergraduate at $20 \%$. The third and fourth years are often critical years for professional development. Also, the high number could have resulted from the fact that the duo is nearing the employment edge. By the current university program, BFST and BHN almost scored equally at $14 \%$ and $13 \%$ respectively while BAGE, MFSQM, were at $6 \%, 2 \%$. Students that fall in other categories other than those listed had only $5 \%$. Students of BFST and BHN consider themselves to interact more with the food industry compared to the BAGE students, therefore explaining the higher numbers for BFST and BHN. Whereas the MFSQM program equally targets the food industry, the low student participation could have been because many of these students were already working and therefore, did not have time for, and interest in participating in fieldwork.

Table 1. Demographic characteristics for the study group

\begin{tabular}{lll}
\hline Item & Freq. $(\mathbf{n}=\mathbf{4 0})$ & Proportion \\
\hline Gender & 25 & $62.5 \%$ \\
Male & 15 & $37.5 \%$ \\
Female & & \\
\hline Level of education & 33 & $82.5 \%$ \\
Undergraduate & 2 & $5 \%$ \\
Graduate & 5 & $12.5 \%$ \\
Other & & \\
\hline Current year of study & 2 & $5 \%$ \\
Undergraduate-Second year & 23 & $57.5 \%$ \\
Undergraduate-Third year & 8 & $20 \%$ \\
Undergraduate-Fourth year & 2 & $5 \%$ \\
Graduate - First Year & 5 & 12.5 \\
Not Applicable & & \\
\hline Current university program & 14 & $35 \%$ \\
BFST & 13 & $32.5 \%$ \\
BHN & 6 & $15 \%$ \\
BAGE & 2 & $5 \%$ \\
MFSQM & 5 & $12.5 \%$ \\
Other & &
\end{tabular}

\subsection{Participation in the EAPI Training Program}

Table 2 provides a summary of the finding of student participation in the EAPI fieldwork. Students were asked about the level of decision making to participate in the training program. The majority of the participants took their own decisions to participate in the fieldwork to gain practical experience (85\%). The other factors (5\%) mildly influenced the student choices to participate in the fieldwork. The students were also asked to define what their expectations for this fieldwork were at the time of application. The need to get a proper direction for better preparation for independent life and the zeal for linking classroom learning to workplace reality merged as the greatest expectations for the fieldwork with $78 \%$ and $75 \%$ respectively. Only $25 \%$ of the respondents needed academic credit from the fieldwork. About 5\% considered reasons other than those provided for participating in the fieldwork. These results are not surprising as finalists and semi-finalists in the fourth and third year of their undergraduate studies, that make the greatest portion of the participants are critical about life outside university. 
Table 2. Percentage and frequencies for items related to participation in the fieldwork

\begin{tabular}{|c|c|c|}
\hline Item & Freq. & Proportion \\
\hline \multicolumn{3}{|l|}{ Reason for participating in the fieldwork } \\
\hline Department course requirement & 1 & $2.5 \%$ \\
\hline Recommended by a friend & 3 & $7.5 \%$ \\
\hline Own decision to gain practical experience & 34 & $85.0 \%$ \\
\hline Others & 2 & $5.0 \%$ \\
\hline \multicolumn{3}{|l|}{ Did you receive proper work and assignment orientation? } \\
\hline Complete and accurate & 29 & $72.5 \%$ \\
\hline Somewhat related & 11 & $27.5 \%$ \\
\hline Had no relevance & 0 & $0.0 \%$ \\
\hline Does not apply & 0 & $0.0 \%$ \\
\hline \multicolumn{3}{|l|}{ The overall level of satisfaction with EAPI fieldwork } \\
\hline Very dissatisfied & 1 & $2.5 \%$ \\
\hline Dissatisfied & 0 & $0.0 \%$ \\
\hline Neither & 3 & $7.5 \%$ \\
\hline Satisfied & 26 & $65 \%$ \\
\hline Very satisfied & 10 & $25 \%$ \\
\hline \multicolumn{3}{|l|}{ Would you recommend this field attachment program to other students? } \\
\hline Highly recommend & 29 & $72.5 \%$ \\
\hline Recommend & 8 & $20 \%$ \\
\hline Recommend with reservations & 3 & $7.5 \%$ \\
\hline Would not recommend & 0 & $0.0 \%$ \\
\hline \multicolumn{3}{|l|}{ Relevancy of program to short- and long-term career interests } \\
\hline Yes & 40 & $100 \%$ \\
\hline No & 0 & $0.0 \%$ \\
\hline \multicolumn{3}{|l|}{ How was the experience related to your major field or career goals? } \\
\hline Very closely & 25 & $62.5 \%$ \\
\hline Related through occasional assignments & 15 & $37.5 \%$ \\
\hline No relationship exists & 0 & $0.0 \%$ \\
\hline Not applicable & 0 & $0.0 \%$ \\
\hline \multicolumn{3}{|l|}{ What kind of impact has this program had on you? } \\
\hline Provided me with a better understanding of my career goals & 24 & $60 \%$ \\
\hline Increased my skills and knowledge in performing a particular activity & 33 & $83 \%$ \\
\hline Changed my attitude or feelings about myself and other people & 22 & $55 \%$ \\
\hline Provided me with the opportunity to apply theoretical concepts to the actual work environment & 30 & $75 \%$ \\
\hline
\end{tabular}

The results indicated that of the 40 respondents, $29(72.5 \%)$ believed that the work and assignment orientation was complete and accurate, while the remaining $11(27.5 \%)$ agree that it was somewhat related. This indicates that work and assignment orientations were generally relevant for the different field activities. Work orientation is important as it instills confidence within workers, helps workers adapt faster to the assignments, makes the workforce more effective and productive, as well as improving communication between workers and the immediate supervisors (Bauer, 2010). 
Students were asked to rate their overall level of satisfaction with the EAPI fieldwork. The results depict that $1(2.5 \%)$ respondent was very dissatisfied, $3(7.5 \%)$ respondents were neither dissatisfied nor satisfied, $26(65 \%)$ respondents were satisfied, while $10(25 \%)$ respondents were very satisfied with the fieldwork. The study was interested in knowing if the participating students would recommend the program to friends and other intending persons. The results indicated that of the 40 respondents, 29 (72.5\%) highly recommend, $8(20 \%)$ recommend, and $3(7.5 \%)$ would recommend the fieldwork with reservations.

Students were asked, 'Has this fieldwork stimulated your interest in the field of food processing? Why or why not?' These are some of the comments from the 40 respondents: (i) "The fieldwork is very practical as it opened new opportunities" (ii) "It showed me how enormous opportunities are in food-related industries as well as enabling me to appreciate value addition as a source of income" (iii) "It enables one have a clear application of classwork to the field" (iv) "We obtained relevant information about certification, quality assurance, waste management, and documentation that are relevant for a legal business" (v) "It helped improve our auditing skills for the food industry" (vi) "We appreciated that one can start a food processing business even with little capital". These thoughts are rich and insightful. They explain the level of mindset change among the students. Skills such as auditing help prepare the student for the food and food processing facilities inspection role, which is one of the core roles for the UNBS. Entrepreneurial ideas generated indicate that participants will always try to create opportunities out of the resources available to them even in the event of scarce formal jobs.

Regarding the relevance of the program to the student's short- and long-term goals, all 40 respondents agreed that the program and its objectives were well aligned with the career interests (Table 2). The study also needed to assess if the experience obtained during the fieldwork was related to career goals. Of the 40 respondents, $25(62.5 \%)$ noted that the experience was very closely related while the other $15(37.5 \%)$ related the experience through occasional assignments. This could be associated with proper and effective program design and implementation. Also, the close relationship between the experience and career goals could explain the very high rating for the relevance of the program to career interests. Assessment of the impact indicates that of the 40 respondents, $24(60 \%)$ agreed that the fieldwork provided them with a better understanding of their career goals, $33(83 \%)$ indicated that it increased their skills and knowledge in performing particular tasks, 22 (55\%) changed their attitude and feelings about self and others, while $30(75 \%)$ had the opportunity to apply theoretical concepts to the actual work environment.

\subsection{Professional Skills Development}

One of the objectives of the fieldwork was to improve professional skills among university students. A summary of the rating in terms of means and standard deviation for the different professional skills is given in Table 3. Results indicate the highest means and standard deviation (SD) were 4.650 and 1.095 respectively. The lowest mean and SD were 4.175 and 0.669 respectively. The means indicate that responses by respondents were shifting from agree to strongly agree for all professional skills. This shows a positive response to all professional skills.

Students were asked, 'In what manner has the fieldwork assignments contributed to your professional development?' These were some of the responses provided: (i) "It increased practical and hands-on" (exposure to different aspects of food processing). This contributes to the level of knowledge transfer among students. According to Sumeracki, Weinstein-Jones, Nebel, and Schmidt (2019), the student's ability to effectively apply the knowledge they learned to new situations completes the cycles of knowledge transfer. (ii) "Improved my social capital'(networking with agro-processors and students from sister programs that focus on food processing - Human nutrition, Food Science, and Agricultural Engineering) (iii) "Improved work ethics especially in terms of time management, effective communication, and reporting" (iv) Problem identification and analysis - "Improved the critical thinking abilities to facilitate the generation of workable and scalable solutions" (v) "Increased urge to use my profession to support the food industry". These comments could potentially explain the very high scores for the different professional development aspects in Table 3. 
Table 3. Mean and standard deviation for the different characteristics of professional development

\begin{tabular}{lll}
\hline Characteristic & Mean & SD \\
\hline $\begin{array}{l}\text { Developing experience in my discipline of study } \\
\text { Interacting and working with people of other cultures and scholarly background }\end{array}$ & 4.300 & 0.980 \\
(inter-disciplinary working) & 4.650 & 0.726 \\
Recognizing the skills, abilities, and needs of others in a team (Emotional & 0.741 \\
intelligence) & 4.275 & 1.095 \\
Ability to work under pressure & 4.550 & 0.835 \\
Planning my time to complete work, class, or volunteer projects (Time management) & 4.550 & 0.835 \\
Organizing my work to complete fieldwork, and school/classwork or volunteer projects & & \\
(Organizational skills) & 4.325 & 0.787 \\
Solving problems related to work, class, or volunteer projects (Problem-solving skills) & 4.575 & 0.738 \\
Communicating effectively in writing & 4.575 & 0.771 \\
Communicating effectively through speaking & 4.325 & 0.959 \\
Leading others when working in groups (Leadership skills) & 4.525 & 0.948 \\
Working with a team to complete Project assignments (Team player) & 4.600 & 0.735 \\
Developing strong work ethics & 4.550 & 0.669 \\
Interviewing skills & 4.500 & 0.922 \\
Working around challenges to accomplish assignments (Perseverance and motivation) & 4.175 & 0.972 \\
Analyzing markets and coming up with new entrepreneurial ideas (Enterprise and & & \\
entrepreneurial skills) & &
\end{tabular}

A scale of 1 to 5 ( 1 - strongly disagree and 5 - strongly agree) was used ( $\mathrm{n}=40$ respondents).

\subsection{Personal Growth}

Using a 5-point Likert scale (1-Strongly disagree and 5 - Strongly Agree), the respondents were asked to rank the extent of change in different aspects of personal growth. The mean and standard deviation (SD) for the different aspects of personal growth are shown in Table 4. The highest mean and standard deviation (SD) was 4.538 and 0.959 respectively. The lowest mean and SD were 4.282 and 0.746 respectively. The mean for the extent of personal growth ranges between 4.282 and 4.538 indicating that responses shift from agree to strongly agree. The responses are positive for all personal growth characteristics.

Table 4. Extent of change on personal growth among students

\begin{tabular}{lll}
\hline Characteristic & Mean & SD \\
\hline These experiences add value to my learning & 4.385 & 0.923 \\
These experiences have a positive impact on my learning & 4.462 & 0.746 \\
These experiences keep me actively engaged in learning & 4.282 & 0.959 \\
These experiences have helped me develop critical thinking skills & 4.538 & 0.746 \\
These experiences have helped prepare me for my career & 4.513 & 0.812 \\
\hline
\end{tabular}

A scale of 1 to 5 (1- strongly disagree and 5 - strongly agree) was used ( $\mathrm{n}=40$ respondents).

\subsection{Mindset Change among Students}

Students were asked to list things they would do different as a result of the fieldwork and these were their comments: (i) To be a job creator and rather not job seeker (start enterprises in agro-processing) (45\%) (ii) Be more resourceful to entrepreneurs in the community (40\%) (iii) Prepare better reports (23\%) (iv) Attend classes with industry perspective 
$(3 \%)(v)$ To work with other people (team player and people management) (30\%) (vi) Never to underestimate career opportunities however small it may be (13\%) (vii) Improve on time management since it is a critical aspect of life (18\%) (viii) Consider consultancy as a career option (10\%) (ix) Engage in similar projects aimed at enhancing agro-processing industry (5\%) and (x) Encourage other students to join such projects since it has a lot of positive impact on career (3\%). From the responses, it is evident that the fieldwork greatly influenced the conduct, mindset, and prospects among the students. The higher mentions for job creation could be attributed to the exposure gained with the agro-processing MSMEs that produce good products using rudimentary methods. The high proportion of students intending to be more resourceful to entrepreneurs in the community could be attributed to the fact that their interaction with the processors helped them appreciate the need to narrow the existing knowledge gap between university and the agro-processors. Because this fieldwork focused on impacting students with skills that enable the agro-processors to attain certification for their products, the skills gained by students can easily be transferred for future employment. Deauville Partnership and IFI Coordination Platform (2012) notes that training programs need to teach skills that are demanded by hiring firms to support future occupational mobility and life-long learning.

\subsection{Improvement in the EAPI Program}

Students as critical beneficiaries from this fieldwork were asked to assess the program and suggest areas that need to be strengthened to have the program better benefit its participants. The following were recommended: (i) Increase contact time between the academia and the industry (ii) Other students especially first and second-year students should be included instead of only finalists and semi-finalists. According to Peacock and Bacon (2018), the early introduction of employment-related skills aids retention in the degree programs as well as preparing students for the internship placements. (iii) Project activities shouldn't coincide with class time so that students can actively participate in project activities and at the same time class activities (iv) The project should allow the students to transform the acquired skills into tangible products (v) To scale up the project to national and regional level because it's very informative for both the agro-processors and students across the board (vi) Enroll student finalists at an early stage to enable them to identify problems in industries and work towards solving them as their final projects (vii) It would be great if the project can be made to contribute to the student academic cumulative grade point average (CGPA). Just like the current internship programs at Makerere University that are graded, assessment of EAPI fieldwork to contribute to CGPA may increase adherence and commitment towards the program (Krawczyk, 2017). (vii) There should be greater awareness about the importance of this program to encourage students to gain interest.

\subsection{Overall Rating of the EAPI Student Skilling Program}

As direct beneficiaries of the EAPI program, students were asked to do an overall program rating. Study findings indicate that of the 40 respondents, $9(22.5 \%)$ believe that they exceeded their expectations, $28(70 \%)$ met their expectations, and only $3(7.5 \%)$ did not meet their expectations. These findings could be attributed to the program design and implementation that considered developing a wholesome student as a professional yet with an entrepreneurial mind.

\subsection{Reliability Analysis}

The responses for the Likert scale for the professional development and personal skills were assessed for reliability using Cronbach's alpha. The Cronbach's alpha helps establish the nature of internal consistency, soundness, and reliability of the scale. Cronbach's alpha values are shown in Table 5. Generally, higher values show a more reliable scale. Results for reliability indicate that Cronbach's alpha values for both professional skills and personal growth are above 0.93 , thus, the scales are sound and reliable.

Table 5. Cronbach's alpha values from reliability tests

\begin{tabular}{lll}
\hline Variable & No. of items & Cronbach's alpha \\
\hline Professional skills & 15 & 0.9612 \\
Personal growth & 5 & 0.9422 \\
\hline
\end{tabular}

\subsection{Limitations of the Study}

The participation in the study was limited to only the 41 FTB students of Makerere University that took part in the EAPI fieldwork. Much as the sample was purposively selected, the number of respondents is rather still small to make 
better statistical inferences. Future studies should consider more participants for the study to have more accurate and reliable results.

\section{Conclusion and Recommendations}

This study evaluated the influence of fieldwork on the professional and personal skills among FTB students of Makerere University. Results indicated that fieldwork stimulates FTB student's interest in the field of food processing, the change in mindset especially concerning job creation, conduct, and prospects for the students. Inclusion of field related activities into the traditional education system better prepares FTB students for employment as well as stimulate their interest in starting individual enterprises, therefore reducing the rate of unemployment and improving the employability rate for students. A study by Sumeracki et al. (2019) reveals that the more opportunities available for the student to practice knowledge transfer, the better their ability to apply information to ill-structured situations that differ considerably from the well-structured problems encountered during lectures and exams.

\section{Conflict of Interest}

The authors declare no conflict of interest.

\section{Acknowledgments}

This work was supported by the Government of Uganda through Makerere University Research and Innovation Fund (RIF) [grant number RIF1/CAES/008]. Special thanks to the various students of Makerere University for supporting this study.

\section{References}

Aliu, J., \& Aigbavboa, C. (2019). Examining the Roles of Human Capital Theory. What next for Construction Industry? Paper presented at the Journal of Physics: Conference Series. https://doi.org/10.1088/1742-6596/1378/2/022057

Anjum, S. (2020). Impact of internship programs on professional and personal development of business students: a case study from Pakistan. Future Business Journal, 6(1), 1-13. https://doi.org/10.1186/s43093-019-0007-3

Baidoo-Anu, D., Owusu Ansah, L., Acquah, M. M., \& Bentil, S. (2019). Challenges Teachers Face In Integrating Fieldwork into Teaching and Learning of Geography in Senior High Schools. Social Science \& Humanities Journal, 3(1), 1435-1444.

Bauer, T. N. (2010). Onboarding new employees: Maximizing success. In SHRM Foundation's Effective Practice Guideline Series (Vol. 7).

Biney, I. (2015). Exploring graduate unemployment problem in Ghana: Challenges and strategies. Journal of Education, 3(2).

Deauville Partnership, \& IFI Coordination Platform. (2012). SHORT-TERM JOB CREATION - LESSONS LEARNED. Retrieved from Washington DC: https://www.afdb.org/fileadmin/uploads/afdb/Documents/Project-and-Operations/Job\%20creation\%20lessons.p df

Dill, K. (2017). Field Education Literature Review: Volume 1. Field Educator, 7(1).

Fedesco, H. N., Cavin, D., \& Henares, R. (2020). Field-based Learning in Higher Education. Journal of the Scholarship of Teaching and Learning, 20(1). https://doi.org/10.14434/josotl.v20i1.24877

Henry, T., \& Murray, J. (2018). How does it feel? The affective domain and undergraduate student perception of fieldwork set in a broad pedagogical perspective. Tuning Journal for Higher Education, 5(2), 45-74. https://doi.org/10.18543/tjhe-5(2)-2018pp45-74

Kefela, G., \& Rena, R. (2007). Human capital investment is a continuous proposition: A study of north east African states. Indus Journal of Management \& Social Sciences, 2(1), 50-65.

Krawczyk, R. M. (2017). Effects of Grading on Student Learning and Alternative Assessment Strategies (MAED Masters). St. Catherine University, Retrieved from https://sophia.stkate.edu/maed/223

Morrissey, J., Clavin, A., \& Reilly, K. (2013). Field-based learning: the challenge of practising participatory knowledge. Journal of Geography in Higher Education, 37(4), 619-627. https://doi.org/10.1080/03098265.2013.794333 
Muhamad, S. (2012). Graduate employability and transferable skills: A review. Advances in Natural and Applied Sciences, 6(6), 882-885.

Naidoo, D., \& van Wyk, J. (2016). Fieldwork practice for learning: Lessons from occupational therapy students and their supervisors. African Journal of Health Professions Education, 8(1), 37-40. https://doi.org/10.7196/AJHPE.2016.v8i1.536

Olabanji, O. E., \& Abayomi, A. A. (2019). Technical Education and Graduates' Employability in Nigeria. Islamic University Multidisciplinary Journal, 6(4), 115-119.

Peacock, J., \& Bacon, K. L. (2018). Enhancing student employability through urban ecology fieldwork. Higher Education Pedagogies, 3(1), 440-450. https://doi.org/10.1080/23752696.2018.1462097

Pheko, M. M., \& Molefhe, K. (2017). Addressing employability challenges: a framework for improving the employability of graduates in Botswana. International Journal of Adolescence and Youth, 22(4), 455-469. https://doi.org/10.1080/02673843.2016.1234401

Results for Development Institute. (2013). Pathways to employability: lessons and case studies for closing the youth skills gap. In.

Riley, E., Bangsberg, D., Perry, S., Clark, R., Moss, A., \& Wu, A. W. (2003). Reliability and validity of the SF-36 in HIV-infected homeless and marginally housed individuals. Quality of Life Research, 12(8), 1051-1058. https://doi.org/10.1023/A:1026166021386

Sarkar, M., Overton, T., Thompson, C., \& Rayner, G. (2016). Graduate employability: Views of recent science graduates and employers. International Journal of Innovation in Science and Mathematics Education, 24(3), $31-48$.

Stokes, A., Magnier, K., \& Weaver, R. (2011). What is the use of fieldwork? Conceptions of students and staff in geography and geology. Journal of Geography in Higher Education, 35(1), 121-141. https://doi.org/10.1080/03098265.2010.487203

Sumeracki, M. A., Weinstein-Jones, Y., Nebel, C. L., \& Schmidt, S. J. (2019). Encouraging knowledge transfer in food science and nutrition education: Suggestions from cognitive research. Journal of Food Science Education, 18(3), 59-66. https://doi.org/10.1111/1541-4329.12158

Tiberious, M., Mwania, J., \& Mwinzi, J. (2016). The Influence of Financial Resources on the integration of the National Goals of Education. International Journal of Education and Research, 4(9), 51-62.

Wright, P. M., McMahan, G. C., \& McWilliams, A. (1994). Human resources and sustained competitive advantage: a resource-based perspective. International journal of human resource management, 5(2), 301-326. https://doi.org/10.1080/09585199400000020 


\section{Appendix}

\section{Student Evaluation of EAPI Field Attachment}

Research Title: Influence of fieldwork on student preparedness for the job market: a case study of EAPI student skills enhancement program

Thank you for taking part in the EAPI student skills enhancement Program. Please answer the questions as honestly as possible. The information you provide us will assist with future planning and decisions for the EAPI Program. All of the information that you provide will be confidential. The purpose of this study is to evaluate the how the fieldwork has influenced the professional and personal skills for students of Makerere University upon completion.

\section{Part 1: Student details}

A1: What is your name and contact?

First name: Last name: Phone contact:

A2: What is your gender?

\section{Male \\ Female}

A3: What is your level of education? (Please choose other if you're not currently enrolled in either undergraduate or graduate program at the university)
Undergraduate
$\square$ Graduate
$\square$ Other

A4: What is your current study program? BAGE- BSc. Agricultural Engineering, BHN-BSc. Human Nutrition, BFST-BSc. Food Science and Technology, MFSQM-MSc. Food Safety and Quality Management

BAGE

$\square \quad$ BHN
$\square$ BFST
$\square$ MFSQM
$\square$ Other (Specify)

A5: What is your year of study?

$\square \quad$ First year
$\square \quad$ Second year
$\square \quad$ Third year
$\square \quad$ Fourth year
$\square \quad$ Not Applicable




\section{Part II: Participation in the EAPI student skills enhancement program}

A6: Why did you decide to become involved in the skills enhancement program?

Department course requirement

Recommended by a friend

Own decision to gain practical experience

Others (Please explain)

A7: What did you expect to gain from internship? (Please tick all that apply)

Academic credit

Link classroom learning to workplace reality

Direction for better preparation for independent life

$\square$ Others (Please explain)

A8: Did you receive a proper work and assignment orientation?

Complete and accurate.

Somewhat related.

Had no relevance.

Does not apply.

A9: What was your overall level of satisfaction with the Field Experience/Apprenticeship in the EAPI program?

Very Dissatisfied

Dissatisfied

Neither

Satisfied

Very Satisfied

A10: Would you recommend this field attachment program to other students?

Highly recommend

Recommend

Recommend with reservations

Would not recommend

A11: Has this fieldwork stimulated your interest in the field of food processing? Why or why not? 
A12: Do you consider the program you participated in to be relevant and meaningful to your short- and long-term career interests?

$\square$ Yes

$\square \quad$ No

Comments:

A13: How was the experience related to your major field or career goals?

$\square$ Very closely related.

$\square$ Related through occasional assignments.

$\square \quad$ No relationship exists.

$\square \quad$ Not applicable (please comment).

Comments:

A14: What kind of impact has this program had on you? (Choose all applicable)

Provided me with a better understanding of my career goals.

Increased my skills and knowledge in performing a particular activity.

$\square$ Changed my attitudes or feelings about myself and other people.

$\square$ Provided me with the opportunity to apply theoretical concepts to the actual work environment.

Comments: 


\section{Part III: Professional skills}

A15: After participating in the Field Experience/Apprenticeship, please indicate your level of agreement with each of the following statements about the influence of fieldwork on professional skills and abilities. Please check the suitable response.

\begin{tabular}{|c|c|c|c|c|c|}
\hline Skill/Ability/Characteristic & $\begin{array}{l}\text { Strongly } \\
\text { Disagree }\end{array}$ & Disagree & Neither & Agree & $\begin{array}{l}\text { Strongly } \\
\text { Agree }\end{array}$ \\
\hline Developing experience in my discipline of study & $\square$ & $\square$ & $\square$ & $\square$ & $\square$ \\
\hline $\begin{array}{l}\text { Interacting and working with people of other cultures and } \\
\text { scholarly background (inter-disciplinary working) }\end{array}$ & $\square$ & $\square$ & $\square$ & $\square$ & $\square$ \\
\hline $\begin{array}{l}\text { Recognizing the skills, abilities, and needs of others in a } \\
\text { team (Emotional intelligence) }\end{array}$ & $\square$ & $\square$ & $\square$ & $\square$ & $\square$ \\
\hline Ability to work under pressure & $\square$ & $\square$ & $\square$ & $\square$ & $\square$ \\
\hline $\begin{array}{l}\text { Planning my time to complete work, class, or volunteer } \\
\text { projects (Time management) }\end{array}$ & $\square$ & $\square$ & $\square$ & $\square$ & $\square$ \\
\hline $\begin{array}{l}\text { Organizing my work to complete field work, and } \\
\text { school/class work or volunteer projects (Organizational } \\
\text { skills) }\end{array}$ & $\square$ & $\square$ & $\square$ & $\square$ & $\square$ \\
\hline $\begin{array}{l}\text { Solving problems related to work, class, or volunteer } \\
\text { projects (Problem solving skills) }\end{array}$ & $\square$ & $\square$ & $\square$ & $\square$ & $\square$ \\
\hline Communicating effectively in writing & $\square$ & $\square$ & $\square$ & $\square$ & $\square$ \\
\hline Communicating effectively through speaking & $\square$ & $\square$ & $\square$ & $\square$ & $\square$ \\
\hline Leading others when working in groups (Leadership skills) & $\square$ & $\square$ & $\square$ & $\square$ & $\square$ \\
\hline $\begin{array}{l}\text { Working with a team to complete Project assignments } \\
\text { (Team player) }\end{array}$ & $\square$ & $\square$ & $\square$ & $\square$ & $\square$ \\
\hline $\begin{array}{l}\text { Donating my time and abilities in working in community } \\
\text { activities (Negotiation and persuasion) }\end{array}$ & $\square$ & $\square$ & $\square$ & $\square$ & $\square$ \\
\hline Developing strong work ethics & $\square$ & $\square$ & $\square$ & $\square$ & $\square$ \\
\hline Interviewing skills & $\square$ & $\square$ & $\square$ & $\square$ & $\square$ \\
\hline $\begin{array}{l}\text { Working around challenges to accomplish assignments } \\
\text { (Perseverance and motivation) }\end{array}$ & $\square$ & $\square$ & $\square$ & $\square$ & $\square$ \\
\hline $\begin{array}{l}\text { Analyzing markets and coming up with new } \\
\text { entrepreneurial ideas (Enterprise and entrepreneurial } \\
\text { skills) }\end{array}$ & $\square$ & $\square$ & $\square$ & $\square$ & $\square$ \\
\hline
\end{tabular}




\section{Part IV: Personal growth}

A16: Rate your level of agreement/disagreement with these statements about Field Experience/Apprenticeship experiences you have had by checking the appropriate box for each statement:

\begin{tabular}{|c|c|c|c|c|c|}
\hline Skill/Ability/Characteristic & $\begin{array}{l}\text { Strongly } \\
\text { Disagree }\end{array}$ & Disagree & Neither & Agree & $\begin{array}{c}\text { Strongly } \\
\text { Agree }\end{array}$ \\
\hline These experiences add value to my learning & $\square$ & $\square$ & $\square$ & $\square$ & $\square$ \\
\hline These experiences have a positive impact on my learning & $\square$ & $\square$ & $\square$ & $\square$ & $\square$ \\
\hline These experiences keep me actively engaged in learning & $\square$ & $\square$ & $\square$ & $\square$ & $\square$ \\
\hline $\begin{array}{l}\text { These experiences have helped me develop critical } \\
\text { thinking skills }\end{array}$ & $\square$ & $\square$ & $\square$ & $\square$ & $\square$ \\
\hline These experiences have helped prepare me for my career & $\square$ & $\square$ & $\square$ & $\square$ & $\square$ \\
\hline
\end{tabular}

A17: In what manner has this assignment contributed to your professional development?

A18: List three things you plan to do differently as a result of this program.

A19: What changes, if any, would you recommend to the EAPI student skilling program?

A20: Overall EAPI student skilling program rating:

1. Exceeded expectations.

2. Met expectations.

3. Did not meet expectations.

4. Unsatisfactory.

Thank you for your feedback

\section{Copyrights}

Copyright for this article is retained by the author(s), with first publication rights granted to the journal.

This is an open-access article distributed under the terms and conditions of the Creative Commons Attribution license (http://creativecommons.org/licenses/by/4.0/). 